\title{
An EU law perspective on the role of legal authorities in the field of renewable energy
}

Citation for published version (APA):

Peeters, M., \& Schomerus, T. (2014). An EU law perspective on the role of legal authorities in the field of renewable energy. In M. Peeters, \& T. Schomerus (Eds.), Renewable energy Law in the EU: Legal perspectives on bottom-up approaches (pp. 10-34). Edward Elgar Publishing. New Horizons in Environmental and Energy Law series https://doi.org/10.4337/9781783473199.00008

Document status and date:

Published: 01/01/2014

DOI:

10.4337/9781783473199.00008

Document Version:

Early version submitted to journal

\section{Please check the document version of this publication:}

- A submitted manuscript is the version of the article upon submission and before peer-review. There can be important differences between the submitted version and the official published version of record.

People interested in the research are advised to contact the author for the final version of the publication, or visit the DOI to the publisher's website.

- The final author version and the galley proof are versions of the publication after peer review.

- The final published version features the final layout of the paper including the volume, issue and page numbers.

Link to publication

\footnotetext{
General rights rights.

- You may freely distribute the URL identifying the publication in the public portal. please follow below link for the End User Agreement:

www.umlib.nl/taverne-license

Take down policy

If you believe that this document breaches copyright please contact us at:

repository@maastrichtuniversity.nl

providing details and we will investigate your claim.
}

Copyright and moral rights for the publications made accessible in the public portal are retained by the authors and/or other copyright owners and it is a condition of accessing publications that users recognise and abide by the legal requirements associated with these

- Users may download and print one copy of any publication from the public portal for the purpose of private study or research.

- You may not further distribute the material or use it for any profit-making activity or commercial gain

If the publication is distributed under the terms of Article $25 \mathrm{fa}$ of the Dutch Copyright Act, indicated by the "Taverne" license above, 


\section{An EU law perspective on the role of legal authorities in the field of renewable energy}

Marjan Peeters and Thomas Schomerus ${ }^{1}$

(Final draft)

Published in:

Marjan Peeters, Thomas Schomerus, Renewable Energy Law in the EU. Legal Perspectives on Bottom-up Approaches, Edward Elgar, Cheltenham, UK 2014, p. 10-34 (Leuphana University research)

See ElgarOnline https://www.elgaronline.com/view/9781783473182.00008.xml

\footnotetext{
${ }^{1}$ Thomas Schomerus and Marjan Peeters were at the time of writing of this chapter members of the research team in the projekt Innovation Incubator, Act. 1.1/CT EnERgioN, sponsored by the European Union with funds from the European Regional Development Fund (ERDF) and by the state of Lower Saxony. The authors thank Jennifer Stephens for her linguistic support on this chapter. The research underpinning this chapter was completed in August 2013.
} 
Abstract:

This chapter maps and analyses the specific position of regional authorities in view of EU climate and energy law. It specifically focuses on the role taken by such authorities in the light of the transition towards a society increasingly employing renewable energy. Section 2 discusses the potential influence exerted by regional authorities through the Committee of the Regions on the development and content of EU climate and energy legislation. Section 3 examines how the Renewable Energy Directive may influence local renewable energy policies, and will particularly point at the need for national governments to set up clear policies for rewarding ambitious local action. Section 4 highlights the specific authorization role regional governments might play in renewable energy projects. Section 5 concludes and gives an outlook on European practice and related research questions. 


\section{Introduction}

This chapter maps and analyses the specific position of regional authorities in view of EU climate and energy law. It specifically focuses on the role taken by such authorities in the light of the transition towards a society increasingly employing renewable energy. In this chapter, we will use the term "regional authorities" which broadly covers sub-national bodies who either hold a regional or local authority electoral mandate, or are politically accountable to an elected assembly. ${ }^{2}$

On-shore wind turbines, biomass installations, hydropower installations and solar panels must always be established in the territory of a regional authority. The part in the transition to renewable energy played by regional authorities will increase, particularly in relation to spatial planning and environmental permits. This increment will occur through the necessary transition from large scale fossil fuel energy generation - for instance large coalfired power plants - towards smaller scale renewable energy generation - for instance photovoltaic installations on private house roofs. Regional authorities' legal positions, their institutional structure and their tasks depend largely on the country's specific constitution, which gives rise to the many different institutional forms of local governance present in EU practice. It is obvious that in order to comply with national renewable energy obligations as imposed by the Renewable Energy Directive 2009/28 (RED) on EU-Member States, adequate local governance regarding the establishment of renewable energy projects is vital. Moreover, authorities' decision-making, where it concerns the authorization of renewable energy projects, must comply with certain RED-standards, particularly those laid down in Article 13. In other words, regional authorities will be influenced by the legal conditions laid down by the RED for implementation by Member States. In this respect, specific choices made by national governments, such as both policies for reaching national renewable energy targets and the establishment of specific national administrative procedures, will also have an impact upon regional authorities. In view of the EU-wide transition towards renewable energy, it is therefore time to analyze the effect of these new requirements on how regional authorities function.

In section 2, this chapter will focus on the potential influence exerted by regional authorities through the Committee of the Regions on the development and content of EU legislation. Section 3 will then examine how the RED may influence local renewable energy

\footnotetext{
${ }^{2}$ This connects to the definition used in Article 300(3) TFEU.
} 
policies, and will particularly point at the need for national governments to set up clear policies for rewarding ambitious local action. Section 4 highlights the specific authorization role regional governments might play in renewable energy projects. Section 5 concludes and gives an outlook on European practice and related research questions.

\section{Regional authorities and EU law}

\subsection{Committee of the Regions}

Regional governments can play a role in the development of legislation at EU level, allowing them to influence its impact on local communities. The forum through which this influence can be exerted is the Committee of the Regions (CoR). This official body, for which a legal base was created by the 1992 Maastricht Treaty, has an advisory function in the course of law-making by the European Parliament, the Council and the Commission. ${ }^{3}$ Where it concerns EU environmental legislation, Article 192 TFEU states that in the course of ordinary legislative procedure the European Parliament and the Council must consult the CoR. This obligatory consultation is also part of the special legislative procedure, requiring unanimous voting in the Council if measures fall within the scope of Article 192(2) TFEU. This article is particularly relevant in the field of energy, since "measures significantly affecting a Member State's choice between different energy sources and the general structure of its energy supply" are covered. The new energy article, Article 194 TFEU, also refers to the ordinary legislative procedure with a CoR consultation requirement. ${ }^{4}$ Nonetheless, Article 192 TFEU remains particularly relevant for renewable energy measures taken with a view to environmental goals as laid down in Article 191 TFEU. $^{5}$ Article 194 TFEU offers limited opportunities for renewable energy measures in relation to climate change, since its second paragraph states that energy measures "shall not affect a Member State's right to determine the conditions for exploiting its energy resources, its choice between different energy sources and the general

\footnotetext{
3 Article 13(4) TEU: "The European Parliament, the Council and the Commission shall be assisted by an Economic and Social Committee and a Committee of the Regions acting in an advisory capacity." Article 300 TFEU provides that the European Parliament, the Council and the Commission "shall be assisted by an Economic and Social Committee and a Committee of the Regions, where they shall exercise advisory functions".

${ }_{5}^{4}$ For the ordinary procedure see Article 289 TFEU and Article 294 TFEU.

${ }^{5}$ Article 192(2) allows EU legislation that interferes with national energy policies - but it is bound to unanimity. See further on Article 194 TFEU Callies and Hey (2013).
} 
structure of its energy supply", but simultaneously refers to the possibility of adopting measures on the basis of the environmental competence, particularly Article 192(2)(c) TFEU. ${ }^{6}$

The general internal market harmonization competence, as laid down in Article114 TFEU - which might also be a legal basis for measures related to renewable energy, as is the case for the sustainability criteria for biofuels and liquid biomass in Article 17 RED - does not refer to such consultation. This means that, in the case of internal market measures concerning renewable energy based on Article 114 TFEU, only the Economic and Social Committee must be consulted. Article 192(2) TFEU explicitly refers to the possibility of Article 114, hence, Article 114 might still be taken as a basis in the case of internal market measures that may have a significant impact on national energy policies. The choice of the correct legal basis (Articles 114, 192(1), 192(2) and 194 TFEU) might become a difficult and sensitive issue for future renewable energy measures, particularly regarding the unanimity requirement for measures affecting specific national energy choices in Article 192(2) and the provision in Article 194 TFEU. The CoR, however, clearly has the legal right to be consulted in the case of measures based on Article 192 and 194, but not for measures based on Article 114 TFEU.

The Lisbon Treaty strengthened the emphasis on regional and local self-government (Article 4(2) TEU). ${ }^{7}$ The principle of subsidiarity, codified in Article 5(3) TEU, now refers explicitly to the possibility of taking action at local level:

[quotation]Under the principle of subsidiarity, in areas which do not fall within its exclusive competence, the Union shall act only if and in so far as the objectives of the proposed action cannot be sufficiently achieved by the Member States, either at central level or at regional and local level, but can rather, by reason of the scale or effects of the proposed action, be better achieved at Union level.[/quotation]

This means that in considerations about the question whether, in cases where there is no exclusive competence, the EU can legitimately take action, the role of regional and local governments should be taken into account.

\footnotetext{
${ }^{6}$ See for an explanation of the historical background Schmitt von Sydow (2011), 33-46. He particularly argues that the rights in Article 194(2) apply without prejudice to the application of other provisions, meaning that the rights may only be executed if this is not infringing other parts of Union law (p. 37).

${ }^{7}$ This article reads: "The Union shall respect the equality of Member States before the Treaties as well as their national identities, inherent in their fundamental structures, political and constitutional, inclusive of regional and local self-government. (...)".
} 
The CoR has the right to bring actions before the Court of Justice of the European Union if the appropriate mandatory consultation in the legislative process has been ignored, or, according to the $\mathrm{CoR}$, if no due regard has been given to the principle of subsidiarity. ${ }^{8}$ Thus far, no such action has been taken. As is often the case in law, the possibility of going to court may already have an influence on decision-making (this can be called the "shadow effect", meaning that certain decisions may be taken knowing that otherwise legal action may follow). In the field of promotion of renewable energy, further examination of this shadow effect is needed.

Membership of the CoR is open to representatives of regional and local bodies who either hold a regional or local authority electoral mandate or are politically accountable to an elected assembly. ${ }^{9}$ The decision-making within the CoR should take place in view of the Union's general interest: the members of the CoR shall not be bound by any mandatory instructions, and they shall be completely independent in the performance of their duties. This seems a paradoxical clause, since it can be questioned whether, in reality, representatives of local governments can act without consideration of their relationship to their electorate. With regard to its position given by the right of actions in Article 263(3) TFEU, as well as in Article $8(2)$ of the Protocol on the Application of the Principles of Subsidiarity and Proportionality, the CoR is, on the other hand, no longer merely an advisory body, but has been awarded additional rights towards parliamentary representation. ${ }^{10}$

By its nature, the ultimate aim of the Committee is to provide a strong voice for regional and local authorities' concerns in the process of establishing EU measures. This is important in such fields where local and regional authorities are deeply involved in the implementation of EU law, as is the case with renewable energy measures and which will be discussed throughout this book.

\subsection{Advice on the Renewable Energy Directive}

\footnotetext{
${ }^{8}$ See Article 263 TFEU ("The Court shall have jurisdiction under the same conditions in actions brought by Committee of the Regions for the purpose of protecting their prerogatives"); see also the explanation on the website of the Committee of Regions cor.europa.eu/nl/about/interinstitutional/Pages/lisbon-treaty.aspx (accessed 19 August 2014). Article 230 TEC did not contain this possibility for the CoR.

${ }^{9}$ Article 300(3) TFEU.

${ }^{10}$ Cf. Suhr (2011).
} 
The CoR submitted advice regarding the Commission's proposal for the RED. ${ }^{11}$ In the following, we highlight three different issues regarding regional authorities.

(a) The Committee emphasized the need for a bottom up-development of renewable energy, and urged the Commission to amend the proposal in order to require the involvement of regional authorities in the formulation of national action plans, and to take this factor duly into consideration when evaluating these plans. ${ }^{12}$ The national renewable energy action plans prescribed by the adopted RED must determine sectoral targets for electricity, transport, and heating and cooling, and describe the policies and measures for reaching them. ${ }^{13}$ Article 4 RED states that cooperation between local, regional and national authorities must be set up as part of the measures deemed adequate for achieving the national overall targets, without going as far as requiring that regional authorities be involved in the national plan-making as recommended by the CoR. ${ }^{14}$ Further research is needed to understand the role played by regional authorities in the overarching policy-making in Member States, regarding the transition towards renewable energy. Can regional authorities really have been involved in plan-making, despite the short-term delivery deadline for the national renewable energy action plans? ${ }^{15}$ How have regional and national government points of view differed? Have these differences been solved?

(b) The Committee opinion lists activities from regional authorities which contribute to the increase of renewable energy, pinpointing, inter alia, spatial planning, the ownership and management of public land and property, transport policies, provision of heating and cooling networks, and communication with citizens. ${ }^{16}$ The Committee implicitly emphasizes its role in dealing with the authorization of renewable energy projects, by urging the Commission to resist the pressure brought to bear on Member States to set up centralized, single administrative bodies dealing with applications and

\footnotetext{
${ }^{11}$ Opinion of the CoR on "Promotion of Renewable Energy" [2008] OJ C325/12. See for the Commission proposal Brussels, COM(2008) 19 final, 23 January 2008.

${ }^{12}$ Opinion of the CoR, paras. 2, 3 and 18.

${ }^{13}$ See Article 4 from Commission Proposal COM(2008) 19.

${ }^{14}$ Article 4(1) RED; see also Preamble, para. 34, which talks about involving as appropriate, regions and local authorities.

${ }^{15}$ The Renewable Energy Action Plans had to be notified by 30 June 2010, while the Directive was adopted on 23 April 2009.

${ }^{16}$ Opinion of the CoR, para. 11.
} 
assistance for renewable installations. ${ }^{17}$ Section 4 of this chapter will discuss more deeply the role of regional authorities in authorizing renewable energy projects.

(c) The Committee stresses regional authorities' role in the fields of education and training. These describe increasing demands by citizens to improve the quality of information, requiring a rise in awareness and communication. ${ }^{18}$ The Committee urges that local and regional authorities are fully involved in the development and implementation of information, awareness, guidance, education and training. It must be understood that efforts to supply information regarding renewable energies are huge. The issue of renewable energy is relatively new, its technology and science are ongoing, and society, both individual citizens and business, needs to adapt to the new energy infrastructure. A decision must be made as to which information should be provided specifically by each and every regional authority. The final provision in the Directive leaves room for Member States to decide how to distribute the responsibility for providing information. It loosely provides that "Member States, with the participation of local and regional authorities, shall develop suitable information, awareness-raising, guidance or training programmes in order to inform citizens of the benefits and practicalities of developing and using energy from renewable sources."19 This leaves the question of how to provide "suitable information" to be decided within the Member States. This specific topic will also, at least partly, be covered by the obligations from the Aarhus Convention (AC) and EU Directive 2003/4/EC on public access to environmental information. This directive obliges Member States, upon request by a citizen, to provide environmental information, through the competent authority, unless a justification of refusal applies. For instance, information regarding wind-turbine noise production is covered by this directive, but other information, such as confidential business information regarding wind-energy production, may be refused. Moreover, Article 5 AC and Article 7 of Directive 2003/4 oblige active provision of information to citizens. It is left to the Member States to define an adequate approach to their obligation of active provision of suitable and accurate information about renewable energy, if requested by a citizen. In this respect, the RED remains vague, but, as far as renewable energy information is covered by the AC and

\footnotetext{
${ }^{17}$ Opinion of the CoR, para. 12.

${ }^{18}$ Opinion of the CoR, para. 28.

${ }^{19}$ Article 14(6) RED.
} 
Directive 2003/4, more concrete legislation applies and, at least partly, fills this gap.[/list]

\subsection{0: New renewable energy legislation?}

The current RED only prescribes renewable energy targets for the year 2020. If the EU wants to continue using renewable energy targets, a new directive will become necessary. Adopting such national renewable energy targets is not essential for achieving an effective climate policy. If the EU-wide greenhouse gas emissions trading mechanism were improved with a more ambitious greenhouse gas emission reduction, the carbon price would be able to rise, making renewable energy relatively cheaper. It is therefore unclear whether the EU really wishes to continue with national targets for the period after $2020 .^{20}$ Nevertheless, it might be that certain specific aspects of renewable energy must be dealt with in a directive, that is, the sustainability requirements for biofuels and liquid biomass (Article 17 RED) or specific requirements for renewable energy authorization procedures (now Article 13 RED). Certainly, with regard to the strengthening of the EU greenhouse gas emissions trading-scheme or the establishment of a new RED, regional authorities will be given the opportunity to offer advice on new EU measures, and to voice specific concerns based on experience gained in the course of giving effect to Directive 2009/28.

\section{The renewable energy directive with regard to ambitious regional action}

\subsection{Implementation choices by Member States in view of the climate and energy package}

EU secondary climate and energy laws consist, for the most part, of directives. As a result of the implementation of these directives by Member States, regional authorities might have obligations and tasks imposed upon them. Although directives cannot impose targets or obligations directly on regional governments, EU legislation contains references to their pertaining responsibilities. The Energy Efficiency Directive, for instance, states that "Public bodies at national, regional and local level should fulfill an exemplary role as regards energy

\footnotetext{
${ }^{20}$ See in this respect European Commission, Green Paper: A 2030 framework for climate and energy policies, COM(2013)169 final, 27 March 2013.
} 
efficiency". ${ }^{21}$ This culminates in the duty of Member States to encourage public bodies, including those at local level, to adopt an energy efficiency plan, which might be either a freestanding plan or part of a broader climate and environmental plan. ${ }^{22}$ As only "encouragement" is prescribed, these obligations remain of a "soft" character. It is therefore up to the Member States to decide exactly how this encouragement should take place. There is a real necessity for Member States to consider deeply how to involve local authorities. This applies not only in matters of energy efficiency but also in the reduction of greenhouse gases not covered by the EU emissions trading scheme, and for the promotion of renewable energy. In other words, Member States generally cannot achieve the binding emission-reduction targets from the Effort Sharing Decision 406/2009 or the binding RED targets without active contribution from regional authorities. The preamble of the Effort Sharing Decision even states: "Since the reduction commitment of the Community imposes tasks not only on the central governments of Member States but also on their local and regional governments and on other local and regional advocacy forums and organizations, Member States should ensure cooperation between their central authorities and local authorities at different levels." (emphasis added). ${ }^{23}$ This exact wording means that, in a legal sense, it cannot be understood as binding obligations on regional and local authorities. The preamble should be read as a political call; Member States cannot fulfill their obligations without the help of regional and local governments. How Member States wish to involve these authorities in the course of compliance with the EU obligation to reduce greenhouse gas emissions from the non-EU ETS sector, remains their sovereign choice. Since the constitutional structure of each Member State is different, each national government must consider how to involve its regional governments within the national effort to comply with EU-climate and energy law. It is, however, clear, that the implementation of various EU secondary acts, that is, the Energy Efficiency Directive, the Effort Sharing Decision and the RED, requires Member States to involve their regional governments in the effort to comply with the numerous EU targets. It will be interesting to see how this will take place in the different Member States: is it more likely to be a top-down movement, in which national governments dictate targets to regional authorities, or will it be a bottom-up development, where regional governments indicate their wishes and problems?

\subsection{National frameworks rewarding ambitious local policies}

\footnotetext{
${ }^{21}$ Directive 2012/27/EU, Preamble, para. 15.

${ }^{22}$ Directive 2012/27/EU Article 5(7).

${ }^{23}$ Decision 406/2009/EC, Preamble, para. 28.
} 
A noteworthy policy among some regional authorities across the EU is their intention to move towards renewable energy improvements. One example is the Covenant of Mayors, a network of regional governments aiming at 20 per cent reduction of $\mathrm{CO}_{2}$ emissions in 2020 . The core instrument is the development and implementation, by each participant, of a Sustainable Energy Action Plan. ${ }^{24}$ Strikingly, each participating regional authority has chosen the same target, in this case a greenhouse gas emission reduction target while, in the case of the Effort Sharing Decision and the RED, the EU approach is based on differentiated targets for Member States. This can mean that a regional authority commits to a more ambitious target than applies to the Member State. In its preamble, the RED even says that Member States may encourage local and regional authorities to set targets in excess of national targets. ${ }^{25}$ The main purpose of the RED is to have achieved at least 20 per cent renewable energy in gross final consumption of energy and 10 per cent renewable energy in transport by $2020 .{ }^{26}$ One of its main instruments is the imposition of mandatory national targets. In order to comply with the binding targets, it is the task of Member States to develop and implement national policies, including support mechanisms and the establishment of feasible administrative authorization procedures. Part of this national policy-making is the consideration of cooperation with other Member States. Article 6 RED allows for the statistical transfer of a specified amount of renewable energy from renewable sources from one Member State to another. If, for example, one Member State has a surplus of renewable energy (more renewable energy consumption than the mandatory target requires) it may transpose this surplus to another Member State facing a compliance problem with the mandatory target. The directive does not give detailed rules specifying if or how this statistical transfer may be conducted. Basic requirements are that (1) a statistical transfer shall not affect the achievement of the national target of the Member State making the transfer, and, (2) a notification be given to the Commission. ${ }^{27}$

It is up to the Member States to choose how to approach their regional authorities in the course of compliance with the mandatory renewable energy target. Part of the national policy might be the development of regional renewable energy targets (which might be split up in, for instance, targets for wind-energy production), for which regional authorities would then be responsible. How regional authorities can be involved, and to what extent binding obligations can be imposed on them, depends, of course, on the constitution of the individual

\footnotetext{
${ }^{24}$ See Peeters (2012).

${ }^{25}$ RED, Preamble, para. 23.

${ }^{26}$ The words "at least" form explicit part of Article 3 RED.

${ }^{27}$ Article 6 RED, paras. 1 and 2.
} 
state. It will be interesting to examine which models have been followed by Member States, and whether any sub-national targets have been set and, if so, in what form, with what status and with what outcome.

In the light of this, it will also be interesting to see whether a "more than business as usual" approach will be chosen, and if regional governments will invest in contributing to an over-achievement by the state. Ambitious regional approaches with regard to energy saving and energy efficiency will also contribute to the achievement of the national renewable energy target. If relatively less energy is consumed, the mandatory target for renewable energy will be more easily reached because of the decline in demand for fossil energy. ${ }^{28}$ It is easy to imagine that ambitious regional authorities contributing towards exceeding the national target, may feel put out should the national government sell any surplus without rewarding them. It remains to be seen what national approaches will be developed in this respect. The national renewable energy action plans (NREAP) show that there has been little discussion on this topic so far. Member States were required to submit these plans by 30 June 2010. The German NREAP, for instance, discusses the possibility of using flexible cooperation mechanisms such as statistical transfer according to Article 6 RED. Germany will probably exceed the 18 per cent target set by Annex 1 of the RED by 1.6 per cent. ${ }^{29}$ There are as yet, however, no concrete plans for a statistical transfer from Germany to other Member States. To a great extent, this percentage of renewable energies is based on regional activities. This can be seen by the fact that a high number of regions and municipalities have decided to become so-called 100 per cent-Renewable-Energy-Regions. ${ }^{30}$ There is, however, no discussion yet on a possible participation of regional and local initiatives in the aforementioned flexible cooperation mechanisms. An extensive strengthening of such ambitious regions could occur if they were given the right to take part in negotiations between Member States on statistical transfer agreement, or in other forms of interstate cooperation.

\section{Decision-making facilitating renewable energy activities}

4.1 The complex maze of applicable public (environmental) law

\footnotetext{
${ }^{28}$ See the reference to energy saving and energy efficiency in Article 3(1) RED last sentence; see also Article 3(1) subpara. 3 of the Energy Efficiency Directive 2012/27/EU concerning the role of renewable energies for the setting of energy efficiency targets.

29 Bundesrepublik Deutschland, Nationaler Aktionsplan für erneuerbare Energie gemäß der Richtlinie 2009/28/EG zur Förderung der Nutzung von Energie aus erneuerbaren Quellen, 2010, p. 104.

${ }^{30}$ See the list of identified 100\%-regions, ibid, p. 178.
} 
The establishment of renewable energy activities by private actors is often covered by several conditional authorizations (like permits) and other public law conditions. Article 13 RED prescribes that the administrative procedures, regulations and codes for the establishment of renewable energy activities should be "proportionate and necessary". The preamble and also Article 13(1)(d) add that the procedures should be "objective, transparent, non-discriminatory and proportionate". ${ }^{31}$ An elaboration of the adequacy of the procedures is given in Article 13(1)(a) to (f), such as, according to Article 13(1)(f), the need to establish simplified and less burdensome authorization procedures for smaller projects and for decentralized devices, where appropriate. These "adequacy" requirements apply to plants and associated transmission and distribution network infrastructures for the production of electricity, heating and cooling from renewable energy sources, and to the process of transformation of biomass into biofuels or other energy products. It is to be expected that the court will apply a broad interpretation concerning the range of activities to be covered, as long as these are activities contributing to the achievement of mandatory renewable energy targets. Since the competence for smaller activities will normally be attributed to local authorities, the special mention of "simplified and less burdensome authorization procedures for smaller projects and for decentralized devices" is particularly relevant for such governments. The crucial questions are the exact definition of "smaller projects", the extent to which administrative burdens can be simplified and reduced, and how appropriate participation procedures can be applied.

\section{Substantive law and renewable energy projects}

From an environmental law perspective, the following laws and related obligations could be applicable for renewable energy projects:

- $\quad$ environmental impact assessment law;

- $\quad$ spatial planning and construction law;

- $\quad$ nature conservation law;

- $\quad$ industrial emissions law;

- $\quad$ energy efficiency law.[/list]

\footnotetext{
${ }^{31}$ Directive 2009/28/EC, Preamble, para. 40.
} 
This list is not exclusive, and it is hence quite possible that other environmental laws might apply. Apart from the above list of applicable laws, specific EU and national legal standards may be relevant dependent on the nature of the renewable energy project. ${ }^{32}$ The list below gives a non-exhaustive first overview of specific possibilities.

- for biomass facilities: air pollution prevention law, waste law, and greenhouse gas mitigation law can be relevant;

- $\quad$ for off-shore wind energy activities, maritime protection law is relevant;

- $\quad$ for on-shore wind energy activities, safety law, landscape protection law, noise protection law, nuisance law regarding shadow and flashing light, and "radiation" law may be relevant;

- $\quad$ for hydropower installations, water quality and quantity laws are relevant;

- for solar energy activities, nature conservation and particularly tree-protection law might be relevant.[/list]

Furthermore, Article 7 of Directive 2009/72, concerning common rules for the internal market in electricity, obliges Member States to apply an authorization procedure for the construction of new generating capacity. This procedure must be conducted "in accordance with objective, transparent and non-discriminatory criteria". Once again, the secondary EU law can be seen to impose certain general criteria to which national decision-making must comply. Also, a list of substantive topics has been listed in Article 7 to be taken into consideration. Environment protection and energy efficiency form part of this list. The national authorization procedure for new electricity generating capacities, in so far as it concerns renewable energy, should also comply with Article 13 RED. One specific question in this respect is the extent to which renewable energy-specific procedures may be applied: is there any justification for adopting less onerous procedural and even substantive standards to this category? The literature has already suggested that infrastructure projects can have accelerated approval procedures, "for instance by setting shorter approval periods for the connection of facilities for power generation from renewable energies". ${ }^{33}$ However, it remains to be seen whether the courts will approve such discrimination between conventional and renewable energies.

\footnotetext{
${ }^{32}$ See for an examination from the perspective of USA environmental law: Wildermuth (2010).

${ }^{33}$ Höppner (2012), p. 158.
} 
The whole legal package applicable to renewable energy activities could be described as a "maze": understanding the whole framework of laws applicable to a specific activity is a complicated task. Moreover, all these environmental laws that determine the authorization of a renewable energy activity must probably comply with the general requirements (later called "adequacy requirements") of Article 13 RED. We state "probably" since the text of Article 13 does not make clear whether it includes all substantive standards which must be met before an authorization is granted. The "Puglia Windmill case", which will be discussed in Section 4.3 of this chapter, indicates however, that substantive decisions such as a total prohibition of windmills for the benefit of nature conservation, is covered by Article 13 RED. Article 13 requires more specifically, that national rules comply with these requirements, but a number of these national rules result from the implementation of EU directives, such as in the field of environmental impact assessments, nature conservation or air pollution. In other words, Article 13 implies checking the way other EU directives have been transferred into national rules, and applied in national practice, with regard to the adequate establishment of renewable energy projects. The approach may differ in each Member State, since the directive does not aim at harmonization but aims at providing instruments to promote renewable energy. ${ }^{34}$ Nonetheless, the fact that the directive explicitly states that administrative procedures, regulations and codes should be proportionate and necessary emphasizes the importance of respecting these principles in the course of the implementation of EU law, also in the case of substantive environmental protection requirements. Moreover, not all administrative procedures relevant for the authorization of renewable energy projects stem from EU directives, particularly, where rules for smaller projects or spatial planning and building are concerned. In that sense, Article 13 RED has a huge impact, at least in a formal sense: all administrative procedures, both those stemming from EU law and also sovereign national procedures, should comply with the adequacy requirements. The fact that the adequacy requirements are quite vaguely determined, allows considerable discretion for Member States, and infringement actions taken by the Commission may only be successful in the case of very clear breaches by Member States.

\section{Procedural law: the Aarhus Convention and renewable energy}

\footnotetext{
${ }^{34}$ As was stated in the Standley case in view of flexible nitrate provisions to be implemented by Member States: C-293/97 [1999] E.C.R. I-2603 (29 April 1999); this can probably also be applied to the general procedural requirements provided by Article 13 RED.
} 
The authorization of renewable energy may be covered by the public participation obligations of the Aarhus Convention (AC) (1998 UNECE Convention on access to information, public participation in decision-making and access to justice in environmental matters). Article 6 of this Convention, to which the EU and all EU Member States are party, prescribes that it be made possible for the public concerned to participate in governmental decisions concerning activities with a potentially significant effect on the environment. ${ }^{35}$ The public concerned should be enabled to enforce this right to public participation before the court (see Article $9(2)$ $\mathrm{AC})$. Article $6 \mathrm{AC}$ contains a list of requirements for the public participation procedure, such as providing information in an adequate, timely and effective manner. Moreover, the procedure needs to operate within reasonable time-frames for the different phases, allowing, inter alia, sufficient time for the public to prepare and participate effectively during environmental decision-making. Here, a delicate balance should be struck between, on the one hand, the adequacy requirements of Article 13 RED and the public participation requirements of the EU. This balance has to be reached in the course of implementing Article 13 RED, which means it is a task for the Member States and their administrative authorities. More research is needed on the integration of Article 13 RED and the requirements of Article $6 \mathrm{AC}$. This also includes the coverage of Article $6 \mathrm{AC}$, particularly the need to determine when an activity like a wind turbine facility or a biomass factory has a significant effect on the environment. ${ }^{36}$ If this is to be answered positively, the public participation procedure must be followed - thereby creating more procedural burdens for the establishment of renewable energy.

Regional authorities have a complicated task when authorizing renewable energy activities. This is not only true in view of the complex applicable substantive and procedural law, but also, as can be seen in several chapters of this book (see Chapter 9 from Barbara Pozzo and Stefano Fanetti and Chapter 10 from Birgitte Egelund-Olsen) in view of dealing with potential citizen resistance to renewable energy projects.

4.2 Focus: environmental impact assessments and public participation

\footnotetext{
${ }^{35}$ Article 6(1)(a) and (b) Aarhus Convention; see also Annex I to this Convention.

${ }^{36}$ See Article 6(1)(b) Aarhus Convention.
} 
The "Environmental Impact Assessment" (EIA) is a typical environmental law instrument for securing the environmental integrity of public decision-making, regarding the authorization of potentially harmful activities. Related to the substantive obligation to conduct an EIA, public participation provisions are provided to enable environmental non-governmental organizations (NGOs) and members of the public to take part in governmental decisionmaking. Clearly, both the substantive requirement to conduct an EIA and the procedural provisions to enable the public to participate in the EIA procedure and the subsequent authorization procedure, represent further efforts in the establishment of renewable energy activities.

Currently, two EU directives govern EIAs: the EIA Directive 2011/92/EU which is applicable to individual projects, and the Strategic Environmental Assessment (SEA) Directive 2001/42/EC applicable to plans and programmes. The SEA Directive, however, does not contain a provision for ensuring public participation in the NREAPs: these procedural provisions are given in Article 4 RED. However, the Aarhus Convention Compliance Committee found that the EU did not have "a proper regulatory framework and/or clear instructions in place" to ensure implementation of Article 7 of the Convention by its Member States, with respect to the adoption of NREAPs. ${ }^{37}$ This means that, with regard to NREAPs, the EU has shown a severe regulatory shortcoming with a view to public participation as prescribed by the AC. Such participation possibilities are also relevant for regional governments, and, as mentioned in Section 2 of this chapter, the CoR has explicitly required involvement of regional authorities in the formulation of national action plans. Whether that has been sufficiently achieved deserves further examination. For instance, it has yet to be determined whether regional authorities are covered by "the public" as defined in Article 2(4) AC.

With the introduction of Article 13 RED, the need for adequate procedures for renewable energy has been highlighted, and it is now obligatory for Member States to use only necessary and proportionate procedures. It must be asked how such procedures might affect the application of the provisions in the light of Article $6 \mathrm{AC}$ and the EIA Directive, since some discretion is allowed to Member States in fulfilling public participation commitments. Moreover, if a national law imposes a broader scope of EIA on renewable energy projects than the EIA Directive, or on the other hand if such law applies procedures for

\footnotetext{
${ }^{37}$ Findings and recommendations with regard to communication ACCC/C/2010/54 concerning compliance by the European Union, adopted by the Compliance Committee on 29 June 2012, paras. 85 and 97.
} 
public participation to renewable energy projects not requiring an EIA, since the project is not deemed to have a "significant environmental effect", this law can be assessed in view of the "proportionate and necessary" requirement of Article 13 RED. This also concerns the additional requirements mentioned in Article 13(1)(a)-(f) RED, such as the requirement of non-discrimination among applicants (Article 13(1)(d)). Clearly, Member States must comply with Article 13 by providing adequate renewable energy procedures. Aligning this with the whole international and EU legal framework might not be easy.

Recently, in October 2012 a legislative process to simplify the EIA procedure was initiated by the European Commission. ${ }^{38}$ The proposal intends to "lighten unnecessary administrative burdens and make it easier to assess potential impacts, without weakening existing environmental safeguards". ${ }^{39}$ This is partly to ensure that EIAs are not required unless significant environmental impacts are clear. ${ }^{40}$ With regard to Article 13 RED which aims at adequate procedures for renewable energy, the simplification put forward by the Commission proposal is relevant, since the intention is for procedures to become more efficient. It can, however, be the case that, with respect to Article 193 TFEU, a Member State wishes to apply a more extensive procedure than prescribed by the new EIA directive. ${ }^{41}$ Should a Member State wish to adopt a more extensive approach than required by EU law, in order to conduct environmental impact assessments not required by EU law, the question of whether this is possible in view of Article 193 TFEU becomes relevant. Currently, different views are taken as to the meaning of Article 193 TFEU, and further case law is necessary in order to understand if and how Member States can apply more extensive environmental impact assessments than are required by EU law. ${ }^{42}$ It will be particularly interesting to see whether, and to what extent, it can be justified by the Member State that a more extensive

\footnotetext{
${ }^{38}$ European Commission, Proposal for a Directive of the European Parliament and of the Council amending Directive 2011/92/EU on the assessment of the effects of certain public and private projects on the environment $\operatorname{COM}(2012) 628$ final, Brussels, 26 October 2012.

${ }^{39}$ ec.europa.eu/environment/eia/review.htm (accessed 19 August 2014).

${ }^{40}$ European Commission, Proposal for a Directive of the European Parliament and of the Council amending Directive 2011/92/EU on the assessment of the effects of certain public and private projects on the environment $\operatorname{COM}(2012) 628$ final, Brussels, 26 October 2012, p. 5. Alongside this, the Commission proposes that inter alia climate change will be reflected in the assessment process. This means that an EIA-report has to discuss the effects on "climate change". In case of renewable energy projects, it will be interesting to see how this discussion will develop. For instance, in case of biomass the discussion on the contribution of biomass to the mitigation of greenhouse gases is complicated (will transport and (indirect) land use change for instance be taken into account?).

${ }^{41}$ Here one can wonder whether more extensive public participation procedures fall under the scope of Article 193 TFEU, since this article refers to "maintaining or introducing more stringent protective measures".

${ }^{42}$ Jans and Vedder (2012) p. 118
} 
requirement in the field of environmental impact assessment complies with the adequacy requirements of Article 13 RED.

\subsection{Emerging case law: Wind Energy in Puglia, Italy}

Notably, one case regarding a substantive conflict involving the establishment of renewable energy has reached the CJEU. ${ }^{43}$ It concerns the prohibition of wind turbines in the light of nature protection and is based on a preliminary question from an Italian court regarding the total prohibition on wind turbines in nature conservation areas in the Puglia region. With this measure, the region aimed to take action against the wide-spread installation of wind energy, following an apparently profitable support mechanism established by the national government. This case is clearly an example of a regional government willing to impose a barrier to further renewable energy establishment. The CJEU explicitly considered the proportionality principle and stated that Article 13 introduces this principle with regard to administrative procedures for the authorization of plants producing renewable energy. The court reasoned:

[quotation]In this regard, the principle of proportionality referred to in Article 13 of Directive 2009/28, which is one of the general principles of European Union law, requires that measures adopted by Member States in this field do not exceed the limits of what is appropriate and necessary in order to attain the objectives legitimately pursued by the legislation in question; when there is a choice between several appropriate measures recourse must be had to the least onerous, and the disadvantages caused must not be disproportionate to the aims pursued (see, inter alia, Case C-331/88 Fedesa and Others [1990] ECR I-4023, paragraph 13, and Joined Cases C-133/93, C300/93 and C-362/93 Crispoltoni and Others [1994] ECR I-4863, paragraph 41). [/quotation] $]^{44}$

This required proportionality test according to Article 13 RED is, however, very flexible. It is hard to predict what its significance for the design and application of national procedures for

\footnotetext{
${ }^{43}$ C-2/10 Azienda Agro-Zootecnica Franchini Sarl v Regione Puglia [2011] E.C.R. I-6561.

${ }^{44} \mathrm{C}-2 / 10$, para. 73 .
} 
renewable energy generation will be. ${ }^{45}$ Furthermore, the language used in Article 13 RED is remarkable, since the text refers to both "proportionate" and "necessary", although, usually, the proportionality assessment includes the necessity test. ${ }^{46}$ In the case of the Puglia ban on wind turbines, the national court must answer the difficult question whether this ban for the sake of nature protection is indeed proportionate and necessary.

Understanding precisely the requirements of Article 13 RED for decision-making regarding renewable energy activities clearly illustrates that an intensive test regarding proportionality leads to court interference in administrative decision-making. ${ }^{47}$ In view of this, one can assume that the potential role of case law might be more on the side of the "procedural" than the "substantive" adequacy. Nevertheless, the above case concerning the ban on wind turbines demonstrates that substantive aspects related to Article 13 can be tested in a court procedure, and that there is a need for administrative authorities to provide adequate justification in case a substantive burden or even a barrier like a ban is introduced for renewable energy activities.

Due to the fact that the national laws of Member States generally acknowledge the principle of proportionality, Article 13 might not require fundamental changes to these laws. This must be individually determined for each and every Member State. Although Article 13 RED provides no direct effect for energy operators, according to general principles of law they can try to claim before a national court that a procedural or a substantive requirement is neither necessary nor proportionate. In a law suit, Article 13 RED can provide an additional argument and strengthen the operator's position.

\subsection{Civil law}

Alongside the list of potential applicable laws listed in Section 4.1, civil law might also be important in the case of the realization of renewable energy activities. The establishment of wind turbines, biomass facilities and hydropower installations may have an impact on the free enjoyment of property, leading to civil law claims being submitted by affected private actors. The legal framework for the protection of the right to property depends on the specific legal system of the Member State, and depending on this, a civil law action might be needed to either prevent a conflict concerning property issues, or to pursue proper compensation. Here

\footnotetext{
${ }^{45}$ Groussot (2006) using the exemplary paragraph title: "The test of proportionality and its flexibility", p. 146.

46 Jans, Senden and Prechal (2010), pp. 108-111.

${ }^{47}$ Jans, De Lange, Prechal and Widdershoven (2006) p. 182.
} 
the question emerges as to just how far the scope of Article 13 RED goes. This article demands that "any national rules" concerning the authorization are proportionate and necessary. A broad interpretation of "any national rules" means that also national civil law procedures are covered. However, as soon as such civil law procedures only concern the interrelationship between private actors and therefore not the relationship between governments and renewable energy operators, this civil law is unlikely to be covered by Article 13. In such cases there is no administrative procedure, regulation or code involved (title of the article) nor any (administrative) authorization, certification or licensing procedure. Although a broad interpretation of "national rules" corresponds with the aim of the directive, that there be an adequate regime for the promotion of renewable energy, one must doubt whether it was the legislator's intention to affect civil law procedures relevant to the establishment of renewable energy activities. It can so far be assumed that civil law falls outside the scope of Article 13 RED, unless this law determines the relationship between an administrative authority and the operator of renewable energy. In essence, as soon as civil law forms part of the authorization, certification or licensing of a renewable energy project, the principles of proportionality and necessity seem applicable.

\section{Conclusion}

This chapter has analyzed the role of regional authorities with regard to the promotion of the use of renewable energies under EU law. Member States have come about half-way towards fulfilling the EU 2020-targets. In November 2012, the European Commission reported that according to the national renewable energy action plans, Member States need to increase the total level of installed capacity for electricity generation from renewable sources from about $174 \mathrm{GW}$ in 2005 to about $487 \mathrm{GW}$ in 2020, although, according to Eurostat, the installed capacity was only $288 \mathrm{GW}$ in $2010 .^{48}$ Large investments must still be made in renewable electricity generation, as well as investments in renewable heating and cooling. This also means that the decision-making, concerning administrative authorizations for such projects, will be an important task for the Member States and their various regions.

\footnotetext{
${ }^{48}$ European Commission, Staff working document: Investment projects in energy infrastructure, Accompanying the document Communication from the Commission to the European Parliament, the Council, the European Economic and Social Committee and the Committee of the Regions, Making the internal energy market work $\operatorname{COM}(2012) 663$, p. 25.
} 
With regard to the fact that most EU legislation is implemented at regional or local level, the CoR could play an important role in representing the regions in its advisory role to EU legislation. According to Articles 192(2) and 194(2) TFEU, the CoR must be consulted on energy-related measures, but not for measures based on the internal market harmonization competence of Article 114 TFEU. With the right of action of Article 263(3) TFEU, the Lisbon Treaty has added another option for the CoR to emphasize regional interests, which has not yet been used. It is difficult to say what impact the CoR has had on the EU-climate and energy package, more particularly on the RED, and what impact it might have on future legislation, in particular concerning the setting of new targets and rules for the period after 2020. Further research is needed with regard to the question whether the concerns of regional authorities have been taken into account sufficiently within the renewable energy-related legislative process at EU level. It can also be questioned whether regional authorities have been sufficiently involved in the development of national renewable energy policies, such as in the development of the NREAPs.

More particularly, it yet remains to be investigated how national governments involve regional authorities in the course of complying with the national mandatory renewable energy target for 2020. In this respect, national governments could consider imposing legally enforceable obligations on regional governments, in accordance with their constitutional law. Many regions and local communities have, on the other hand, voluntarily set their own renewable energy targets, several even 100 per cent-regions, as well as commitments within the Covenant of Mayors-network. Such ambitious regional action must be better recognized by the Member States, perhaps including the development of special regulatory approaches. Specifically, it remains to be analyzed whether or how regions can take part in flexible cooperation mechanisms under the RED, such as statistical transfers between Member States. Regional activities which contribute to a Member State's performance in exceeding the EU targets for renewable energies could, for instance, be rewarded through financial or other advantages.

The establishment of renewable energy projects is a complex issue regulated by a "maze" of various laws, through which regional authorities in particular will need to navigate. Article 13 RED aims at the proportionality and necessity of national administrative procedures, regulations and codes. The CJEU decision in the Italian Puglia case shows that Article 13 is not merely symbolic and that even substantive measures may be assessed. It cannot simply be assumed that national administrative laws already comply, both in a 
procedural and a substantive manner, with the "adequacy" principles. Not only national law but also EU law should be examined in the light of Article 13 RED. For instance, the rules of EIA should consider that measures must be necessary and proportionate with regard to the promotion of renewable energies. On the other hand, this could lead to procedural provisions becoming advantageous for energy operators, but where environmental and civil concerns might not be taken sufficiently into account. In this vein, a difficult balance must be struck by both the EU and national legislators. It is self-evident that such procedural laws have a huge impact on the regional authorities often given the task of applying them. Moreover, these authorities need well-designed procedures for legitimately coping with potential civil protest against renewable energy measures.

In the foreseeable future, further legal conflicts regarding the administrative decisionmaking for renewable energy in the light of Article 13 RED might likely arise. When Member States continue to act in the spirit of Article 13 RED, this might even constitute a "special administrative law" for renewable energy projects, with the possibility of favouring renewable energy projects (both procedural and substantive) above other energy projects. The question remains as to how this will have an impact upon regional authorities, particularly in terms of their responsibility to apply adequate procedures for renewable energy projects, while simultaneously ensuring sufficient environmental protection and public acceptance of this enormous transition in society. 


\section{REFERENCES}

Calliess, Christian and Christian Hey (2013) "Multilevel Energy Policy in the EU: Paving the Way for Renewables?", JEEPL 10(2), 87-131.

Groussot, Xavier (2006), General Principles of Community Law, Groningen: Europa Law Publishing.

Jans, J. H., R. de Lange, S. Prechal and R.J.G.M. Widdershoven (2006), Inleiding tot het Europees bestuursrecht, 2nd edn, Nijmegen: Ars Aequi Libri.

Jans, J. H. and H. H. B. Vedder (2012), European Environmental Law, 4th edn, Groningen: Europa Law Publishing.

Jans, J. H., L. A. J. Senden and A. Prechal (2010), Europees Recht, Algemeen deel, (2010), Groningen: Europa Law Publishing.

Höppner, Thomas (2012), "Regulating Investments in Energy Networks - Trade Offs Between Economic and Ecological Goals”, in Michael Rodi (ed.) Energy Infrastructure and Policy Options for a Sustainable Future, IKEM, Berlin: Lexxion.

Peeters, Marjan (2012), "Local Climate Action in the European Union", in Benjamin J. Richardson (ed.), Local Climate Change Law: Environmental Regulation in Cities and Other Localities, Cheltenham, UK and Northampton, MA, USA: Edward Elgar, 273-99.

Schmitt von Sydow, Helmut (2011) "The Dancing Procession of Lisbon: Legal Bases for European Energy Policy”, European Energy Journal, 1(1), October, 33-46.

Suhr (2011) in Christian Calliess and Matthias Ruffert (eds), EUV/AEUV, Das Verfassungsrecht der Europäischen Union, 4th edn., Munich: C.H.Beck, Art. 300, no. 34.

Wildermuth, Amy J. (2010), "Is Environmental Law a Barrier to Emerging Alternative Energy Sources?" 46 Idaho L Rev 509. 